\title{
The Interplay between Teacher-Centredness and Self-Critical Tendency among Malaysian ESL Learners: New Insights for the Asian Context
}

\author{
Siew Ming Thang \\ Prof., Universiti Kebangsaan Malaysia,thang@ukm.edu.my \\ Nurjanah Mohd Jaafar \\ Miss, Universiti Kebangsaan Malaysia,nurjanah@ukm.edu.my
}

Over the last decade, issues regarding attributions for success and failure in the learning of English have garnered much interest among Asian researchers. Of particular interest is the tendency of Asian learners to be self-critical when it comes to attributions for failure in the learning of English. This tendency has commonly been linked to the influence of the socio-cultural context in which the learners have grown up and has been described as a prevalent trait among collectivist societies such as those that exist in many Asian countries. More recently, it has been suggested that a contributory factor for this behaviour is the students' high respect for teachers. The present study was an attempt to investigate to what extent that claim is true. The researchers examined whether or not there is a relationship between self-critical tendency and teacher-centeredness between students of different proficiency levels in the learning of English in a Malaysian context. A mixed-method design comprising questionnaires and individual group interviews was employed. The findings revealed that in general learners who displayed teacher-centred tendency were likely to be self-critical by attributing failure to personal factors. However, difference in proficiency levels did account for some variation in results. Although both tendencies should be seen in a positive light, recommendations with regard to educational implications are outlined.

Key Words: autonomy, attribution, teacher-centred learning, self-critical tendency, English as a second language

\section{INTRODUCTION}

Attributions have been defined in a variety of ways but a commonly accepted way of defining 'attributions' is as "the internal (thinking) and external (talking) process of interpreting and understanding what is behind our own and others' behaviors" (Manusov \& Spitzberg, 2008, p. 38). Thus, this concept is concerned with the 'how' and the 'what' by which people process information in attempting to understand, judge, and act on 
events. Studies on attributions allow researchers to explore learners' justifications for their past behaviours and actions.

Weiner's attribution theory $(1974,1992)$ which is one of the most prominent theories in the area, points out the influence of learners' current self-perceptions on their interpretation of the success and failure brought about by their current efforts. This in turn will influence the likelihood of the same behaviours being repeated in the future. Weiner asserts that people attribute success and failure to factors that lead them to feel good about themselves. Should a learner succeed at an academic task, they will have the tendency to credit this success to personal factors such as their own ability or effort. On the other hand, external factors like poor classroom environment or poor teaching are more likely to be blamed for failure. However, recent studies that looked into Asian learners' attributions for success and failure in the learning of English have revealed patterns that differed from those proposed by Weiner. Of particular interest is the tendency of many Asian learners to be self-critical when it comes to their poor English performance. Studies have shown that Asian learners tend to blame personal factors for their poor performance and credit others for their success (Gobel et al., 2011; Mori, Mohd Nor, Suppiah, \& Oon, 2011; Thang, Gobel, Mohd Nor, \& Suppiah, 2011).

Thang et al. (2011) proposed that a contributory factor for this behaviour is students' high respect for their teachers. They, however, have not confirmed their postulation with empirical evidence. The present study intends to address this gap in knowledge by investigating whether or not there is a relationship between self-critical tendency and teacher-centredness among Malaysian English as a Second Language (ESL) learners in local universities. In particular, the researchers intend to examine the following:

1. How prevalent is the relationship between self-critical tendency and teachercentredness among Malaysian English as a Second Language (ESL) students?

2. Is this relationship influenced by differences in English proficiency levels among the students?

To obtain answer to these research questions, both quantitative and qualitative tools were utilised. The questionnaire identified students' predominant learning preferences and attribution patterns. This was followed by semi-structured interviews which were conducted on selected students from a Malaysian public university. Previous studies undertaken on Malaysian students have revealed them to be mostly teacher-centred (Thang, 2009; Thang \& Alias, 2007) and self-critical (Mohd Jaafar \& Thang, 2013; Mori, Gobel, Thepsiri, \& Pojanapunya, 2010; Thang et al., 2011). However, as mentioned earlier, the relationship between these two sets of characteristics has not been established. Hence, that is the primary goal of this research study.

\section{LITERATURE REVIEW}

\section{Attributions}

The present study anchors on two theoretical models related to human behavior, thinking and learning. The first, the attributional model of achievement motivation, is discussed in this section. This model centres on learners' causal attributions for achievement, i.e. the perceived reasons for success and failure (Weiner, 1974). 
According to Weiner's attribution theory, we use four most common elements of ascription to interpret and predict the outcome of previous achievement-related events which are the degree of effort expended (effort), the difficulty of the task in question (task difficulty), the degree to which luck influenced the outcome (luck) and the level of ability to complete the task (ability).

In his analysis of achievement attributions, Weiner classified attributions into three dimensions:

1. locus or locus of control, comprising attributions that are either internal or external to an individual,

2. stability, referring to attributions that are stable or open to change, and

3. controllability, consisting of attributions that are either within or outside of an individual's control.

The present study uses Gobel et al.'s (2011) dimensional classification scheme that extends Weiner's model as seen in Table 1.

Table 1

Gobel et al.'s dimensional classification scheme for causal attributions

\begin{tabular}{llll}
\hline & \multicolumn{2}{c}{ Dimension } & \\
\hline Attribution & Locus & Stability & Controllability \\
\hline Ability & Internal & Stable & Uncontrollable \\
\hline Effort & Internal & Unstable & Controllable \\
\hline Strategy & Internal & Unstable & Controllable \\
\hline Interest & Internal & Stable & Controllable \\
\hline Grade & Internal & Stable & Controllable \\
\hline Preparation & Internal & Unstable & Controllable \\
\hline Enjoyment & Internal & Stable & Controllable \\
\hline Teacher (influence) & External & Stable & Uncontrollable \\
\hline Class & External & Stable & Uncontrollable \\
\hline Level & External & Stable & Uncontrollable \\
\hline Luck & External & Unstable & Uncontrollable \\
\hline Task (difficulty) & External & Stable & Uncontrollable \\
\hline Source: & & &
\end{tabular}

Source: Gobel et al. (2011)

Attribution theory assumes that everyone has the tendency to self-enhance when searching for causal attributions by taking credit for their own success rather than being accountable for failure (Kruger, 1999). The theory also introduces the concept of egoprotective bias which involves us blaming external, instead of personal factors for our own failure.

The self-enhancing and ego-protective tendencies however are found lacking, and to some, absent in many Asian learners. Instead, a contradictory attribution pattern is more evident, i.e. self-criticism (Gobel et al., 2011; Mori et al., 2011; Thang et al., 2011). Kitayama, Markus, Matsumoto and Norasakkunkit (1997) explained that by being selfcritical, the interconnectedness among members of a collectivist society is enhanced as 
this practice avoids assigning blame to others in the society. Conflicting biases such as self-enhancement and ego-protective biases may therefore jeopardise this value.

The above argument suggests that certain socio-cultural factors are capable of moulding one's attribution pattern. This argument has been supported by empirical studies conducted in many Asian contexts. For instance, Mori et al.'s (2010) comparative study on Thai and Japanese university students' attributions in an EFL context discovered the presence of self-critical tendency in both groups of students in attributing poor performance to internal factors and ascribing good performance to external factors. Moreover, the theoretical structure of causal attributions between the two groups was also quite similar, suggesting a possible cultural bias in attributions in a number of Asian cultures.

Gobel et al.'s (2011) follow-up study compared Thai, Japanese and Malaysian learners' performance attributions. The students in this study similarly displayed a self-critical tendency. The influential role of socio-cultural factors can also be seen from Thang et al.'s (2011) study on students from six Malaysian universities. Two communal characteristics were apparent among the students; high respect for teachers and selfcritical tendency. Both were more apparent among the students of one particular university, who were mostly Malays. The researchers suggested that the Malay students' tendency to demonstrate high respect for their teachers may encourage them to attribute good performance to their teachers. They also proposed that the presence of self-critical tendency may be due to learners' tendency to respect the authority, particularly their teacher, suggesting the possible relationship between the two. The truth of this postulation will be investigated in the current research study.

\section{Autonomy}

The second theoretical model supporting this study is autonomy in learning which refers to a person's ability to take charge of his/her own learning (Holec, 1981). It is a concept that is often associated with independence and individualisation (Benson, 2011; Schmenk, 2005). These values are synonymous with individualistic Western cultures and contradict some of the values that are characteristic of the more interdependent and collectivist Asian cultures (Kitayama et al., 1997; Thang, 2009).

The significant influence of the learners' socio-economic environment on autonomy in the Malaysian context can be seen in Thang's studies on autonomy (Thang, 2009; 2012; Thang \& Alias, 2007). In the studies, learners in general showed a preference for more teacher-centric rather than autonomous characteristics. Generally, they preferred their teachers to guide them and provide them with constant feedback. Despite such tendency, the respondents did display autonomous characteristics. This is especially true in the case of students who were enrolled in a private university (Thang, 2009). The reviewed studies suggest that the manner in which Malaysian learners are brought up and educated encourage them to prefer a teacher-centric approach to learning. However, they seem to have the potential to shift to a more autonomous position if exposed to an environment that requires them to be so as verified by Thang's (2009) study on patterns of behaviour of students in a private university. 
It is commonly believed that this teacher-centred tendency in Malaysia is a result of a very top-down educational system where the directives coming from the Ministry of Education will be issued to schools, and teachers and students have to abide by them. This passive approach has instilled in teachers and students a preference for a passive approach to giving and receiving learning (Murugaiah, 2012; Phan, 2012).

\section{METHOD}

\section{Design}

The study employed the sequential explanatory design whereby quantitative data were first collected through administration of a set of questionnaires and analysed before the collection of qualitative data through semi-structured interviews (Creswell, 2008). This design was felt most appropriate for this study as the problem dealt with could not be sufficiently addressed by a single approach (Creswell, 2008). The first database, i.e. the quantitative data, functioned to identify the trend(s) displayed by the students concerned but could not explain why they displayed such tendency. A second database which provided more depth and insight was therefore necessary to interpret the findings gained from the first database.

\section{Sampling and Participants}

169 students at a Malaysian public university who were taking an English for Academic Purposes (EAP) course participated in the study. They were grouped into two categories, low proficiency (LP) and high proficiency (HP) students based on their performance in the Malaysian University English Test (MUET). Malaysians are required to take this test for admission to local tertiary institutions. Those who scored Bands 1 and 2 (the lowest two bands) were categorised as LP, whereas those who scored Bands 3 and 4 were categorised as HP students. None of the study participants scored Band 5 or 6 (the two highest bands) in their MUET.

The sample was selected using a non-probability sampling technique as this was more feasible in terms of time and resources available at the time of the study. Since the researchers only had access to EAP students from one of the university faculties, the sample comprised only students from the faculty of Social Sciences and Humanities. For selection of interview participants, purposive sampling was employed. Six participants were chosen based on certain criteria determined from their responses to the questionnaire. These criteria are explained in the data analysis section.

\section{Instruments}

Questionnaire

A questionnaire comprising three sections was administered during an EAP class. Section 1 gathered demographic information on participants. Section 2 consisted of items drawn from the Learner Autonomy Characteristics Questionnaire (LACQ), adapted from a previous study (Koo, Thang, \& Lee, 2005). It contained 18 items on inclination towards teacher-centred and autonomous learning. The four-point Likert scale (4 for strongly agree, and 1 for strongly disagree) was used. The reliability coefficient for LACQ was 0.76 . 
Section 3 was divided in two. Part A comprised the Attributions to Success Questionnaire (ASQ), whereas Part B, the Attributions to Failure Questionnaire (AFQ). For both ASQ and AFQ, the participants were asked to choose one activity from a list that they considered they were most successful (ASQ) and poor (AFQ) at. They then rated causal attributions for the selected activities using the same four-point Likert scale used for the LACQ. The ASQ and AFQ were adapted by Gobel and his team of researchers (Gobel et al., 2011; Mori et al., 2010; Mori et al., 2011; Thang et al., 2011) and from Vispoel and Austin's (1995) questionnaires. In the present study, the reliability coefficients for the ASQ and AFQ were 0.70 and 0.74 respectively. The questionnaire was translated into the Malay language.

\section{Interviews}

The semi-structured interviews comprised one section on teacher-centredness/autonomy and another on attributions. In the first section, each participant's account of learning English from a teacher and learning it independently was recorded. The second section recorded their perception of their own English ability and the underlying reasons behind it.

\section{Data Analysis}

Out of the total 169 questionnaires administered, 137 were used for analysis. Altogether, there were 76 LP and 61 HP learners. For the quantitative analysis, factor and frequency analyses were carried out to identify the learners' predominant learning preference and attribution pattern.

For the qualitative analysis, the six interviews were transcribed and initial coding of data was first conducted by assigning category codes. Next, the researchers conducted focused coding by eliminating or combining similar patterns and subdividing or reclassifying new or emerging patterns. Responses that suggest learners' tendency to be self-critical for instance were subdivided to different types of personal factors such as lack of effort and ability. Additionally, responses that point towards their need for a teacher were scrutinised further to explore what roles they needed their English teacher to play. The eventual list was arranged into tables to allow ease of comparison between participants within and across categories.

\section{FINDINGS}

\section{Quantitative Analysis}

\section{LACQ Items}

Factor analysis was carried out on the combined LP and HP groups to group items that were closely related to each other. The varimax $\mathrm{R}$ (orthogonal) rotation and Kaiser normalisation procedure were used to compare factors amongst learners. To increase efficiency, items that loaded below 0.4 (items number 9 and 15) were eliminated. Additionally, lower loadings in cases of cross-loadings of items were also removed.

This procedure was conducted three times as it was difficult to distinguish factors that were extracted in the first two tries. On the third try, a more clear-cut pattern emerged. This two-factor solution had an explained variance at $42.1 \%$. An analysis of the items in 
each factor revealed two different types of learning preferences. Factor 1 represents the 'teacher-centred' group as it generally comprises items that indicate strong features of teacher-centredness, such as regarding teachers as a resource to identify and correct mistakes and preferring teachers to keep giving feedback. A few items indicating autonomy also feature in Factor 1 such as having the desire to self-correct mistakes and taking initiative in learning but these items are not strong expressions of autonomy.

Factor 2 on the other hand represents the 'autonomous group'. The items listed in this factor indicate strong expressions of autonomy such as having the desire to choose what, where and how to learn, believing that learners should be bold enough to challenge their teachers and disliking being directed on how to learn. (See Table 3 for a complete list of items in Factors 1 and 2).

Table 3

Characteristics of Factors 1 and 2

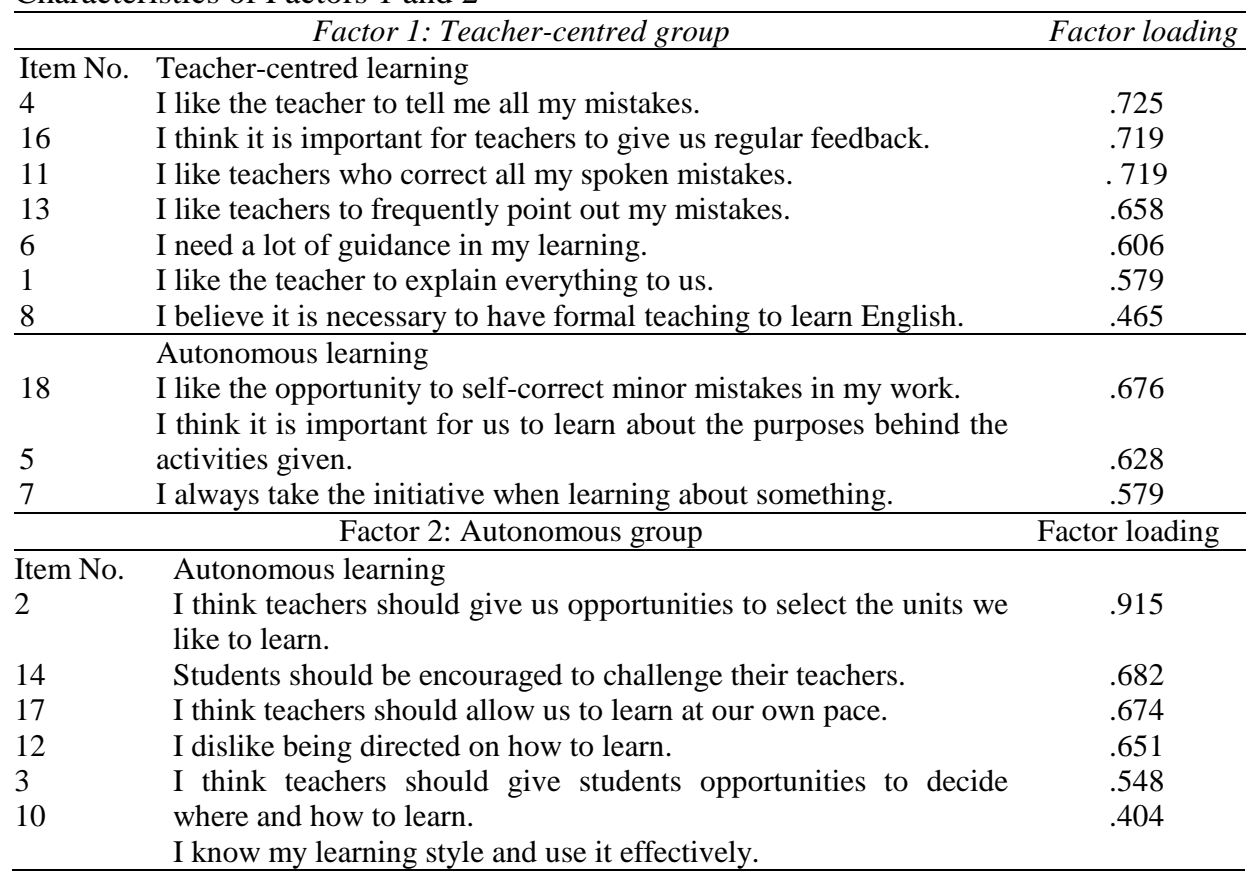

Note. Items number 9 and 15 were deleted as loadings are below 0.4

To come up with the classification of predominant learning preference, each learner's mean score for all items from Factor 1 was calculated and compared with their mean score from Factor 2. Those who scored higher mean scores for items in Factor 1 were classified as 'teacher-centred' learners and those with higher mean scores for items in Factor 2 were classified as 'autonomous' learners. Following that, frequency analysis was carried out to find out the predominant learning preference of low and high proficiency learners. 
The results indicate that a large majority of learners, regardless of their English proficiency level, preferred teacher-centred to autonomous learning: 70 (94.59\%) LP learners and $52(86.67 \%)$ HP learners. However, a slight difference of $7.92 \%$ between the two groups, tentatively suggests that less HP learners preferred the teacher-centred approach as opposed to the LP. Additionally, more HP than LP learners displayed a preference for autonomous learning, i.e. $8(13.33 \%)$ as opposed to $4(5.41 \%)$ LP's. These findings suggest that even though both proficiency groups preferred the teachercentred mode of learning, the HP group appeared to be slightly more inclined towards autonomy.

\section{$A S Q$ and $A F Q$ Items}

For calculation of predominant attribution pattern of each student, the attributions in ASQ and AFQ were first divided into two categories. Ability, effort, strategy, interest, grade, preparation and enjoyment were placed into the 'internal' group, whereas luck, teacher, task, class and level were placed into the 'external' group (c.f. Gobel et al., 2011). Mean score for each category was calculated and compared using the same procedure as the classification of predominant learning preference. Next the influence of English proficiency on attributions was examined through frequency analysis. Table 4 displayed the categorisation of learners into their respective group.

Table 4

Categorisation of LP and HP learners into ASQ and AFQ groups

\begin{tabular}{lccccc}
\hline \multirow{2}{*}{ Grouping } & & \multicolumn{3}{c}{$A S Q$} & \multicolumn{3}{c}{$A F Q$} \\
\cline { 2 - 6 } Internal & & LP & HP & LP & HP \\
& $\mathrm{n}$ & 30 & 25 & 40 & 33 \\
\multirow{2}{*}{ External } & $\mathrm{n}$ & 43.47 & 43.1 & 57.97 & 57.89 \\
& $\%$ & 39 & 33 & 29 & 24 \\
& & 56.52 & 56.9 & 42.03 & 42.11 \\
\hline
\end{tabular}

The frequency analysis shows that learners from both proficiency groups generally attributed their success to external than internal factors. In the case of failure, both groups tend to blame internal factors more than they blame external factors. The tendency to credit success to external factors and blame internal factors for failure suggests a higher inclination towards self-critical tendency among the learners regardless of their proficiency levels.

\section{Comparing the Relationship Between Autonomy and Attributions}

To compare this relationship, frequency analyses were undertaken (results displayed in Tables 5 and 6). For attribution for success, learners (from the HP and LP groups) who displayed teacher-centred tendency were likely to attribute their success more to external factors as shown in Table 5. The findings further suggest that a higher percentage of HP learners credited their success to external factors compared to the LP group but in view of the small difference in number, it is more appropriate to say that both groups generally attributed their success to external factors over internal factors. For LP autonomous learners, it would appear that the percentage who attributed success to external and internal factors is the same. However, the percentage of HP autonomous 
learners that attributed success to internal factor is higher. Thus it would appear that there is an inclination to attribute success to internal factors in the case of HP autonomous learners but in view of the small sample size (only seven learners) it is safer to interpret this finding with caution until it is verified by a bigger sample size.

Table 5

Categorisation of LP and HP learners into ASQ groups

\begin{tabular}{lllll}
\hline Proficiency & Preference & Grouping & $n$ & $\%$ \\
\hline LP & TC & Internal & 29 & 46.02 \\
& & External & 34 & 53.97 \\
\cline { 2 - 5 } & AT & Internal & 2 & 50 \\
& & External & 2 & 50 \\
\hline HP & TC & Internal & 20 & 40.0 \\
& & External & 30 & 60.0 \\
\cline { 2 - 5 } & AT & Internal & 4 & 57.16 \\
& & External & 3 & 42.83 \\
\hline
\end{tabular}

In the case of attribution for failure, Table 6 reveals that the LP and HP learners who displayed teacher-centred learning characteristics were more inclined to attribute failure to internal factors. With regard to the autonomous learners, the percentage of LP and HP learners who attributed success to external factors is higher. Although the number of learners involved is small this finding is rather noteworthy especially in the case of the HP learners where five out of seven attributed their failure to external factors.

Table 6

Categorisation of LP and HP learners into AFQ groups

\begin{tabular}{lllll}
\hline Proficiency & Preference & Grouping & $n$ & $\%$ \\
\hline LP & TC & Internal & 37 & 57.81 \\
& & External & 27 & 42.19 \\
\cline { 2 - 5 } & AT & Internal & 1 & 33.26 \\
& & External & 2 & 66.74 \\
\hline HP & TC & Internal & 31 & 63.27 \\
& & External & 18 & 36.73 \\
\cline { 2 - 5 } & AT & Internal & 2 & 28.56 \\
& & External & 5 & 71.44 \\
\hline
\end{tabular}

The results revealed that teacher-centred learners, regardless of their proficiency levels, were self-critical of their own performance. However, there is also some indication that HP autonomous learners were less self-critical and had greater tendency to blame external factors for failure. However, on the whole it would appear that proficiency levels do not have a major influence on the relationship between autonomy and attributions.

\section{Qualitative Analysis}

To provide deeper insights into the relationship between teacher-centredness, autonomy and attributions, semi-structured interviews were conducted. Based on their predominant learning preference and attribution pattern, HP and LP learners were categorised into one of the following types: teacher-centred and self-critical, teacher-centred and non- 
self-critical, autonomous and self-critical, or autonomous and non-self-critical. In the end, six learners volunteered to participate in the interviews. Table 7 reports their characteristics:

Table 7

Characteristics of interview participants

\begin{tabular}{llll}
\hline Student & Proficiency & Learning preference & Attribution pattern \\
\hline A & High & Teacher-centred & Self-critical \\
\hline B & High & Teacher-centred & Non self-critical \\
\hline C & Low & Teacher-centred & Non self-critical \\
\hline D & High & Autonomous & Non self-critical \\
\hline E & Low & Autonomous & Non self-critical \\
\hline F & High & Autonomous & Self-critical \\
\hline
\end{tabular}

Responses of students A, B and C who were classified as teacher-centred learners were analysed first. Their responses clearly indicate their teacher-centred characteristics.

Student A (HP): (I learn better) when there is someone to encourage me, to push me.

Student B (HP): I really need a teacher. I rely on the teacher to strengthen my understanding of English.

Student C (LP, teacher-centred): ... the best foundation in obtaining knowledge is, there must be a teacher. Teachers are important. If we do not understand something, we can refer to the teachers.

Interestingly even students ( $\mathrm{E}$ and $\mathrm{F}$ ) who were classified as autonomous learners seemed to feel that the teachers were indispensable.

Student E (LP): If s/he is not around, I feel it will be a bit difficult, to give us guidance and all.

Student F (HP): Because when we learn on our own, we will need explanations, right? When we learn from books, or the Internet, we may not necessarily understand (what we learn). Sometimes, they mean different things. That is why I feel that learning from a teacher is necessary.

Only Student D seemed to display typical characteristics of an autonomous learner:

Student D (HP): I think I prefer to learn English on my own.

I think (it is) better, I just learn on my own.

Next, the interview data on attribution patterns were scrutinised. According to the classification, Students A and F belonged to the self-critical category. Their responses when asked about their performance in learning English, clearly reflect this tendency.

Student A (HP): (I am) not confident. (I am) worried that I would make a mistake.

(I am) not (successful) yet. Back then, even until this time, when we learn we must learn grammar, grammar. But I still cannot master (it). 
Student $\mathrm{F}$ (HP): I think it (poor performance) is my fault.

Because maybe I do not have enough focus, which means like, I think I'm still lacking in learning English. Not enough practice.

Students B, C, D and E belonged to the non-self-critical category. However, on analysing the interview data, it was found that Students B and D possessed some nonself-critical characteristics and some self-critical characteristics. Student B (HP) "blamed the teachers when they fail to capture the students' interest into listening to what he/she is saying" but she did say that effort should come from herself too as indicated below:

(I will blame) the teachers because there should be a win-win situation, right? So when we, I, have shown the interest to learn ESS (the EAP course) at the onset, because I truly wanted to learn English, yet the teacher does not have the means to attract the student's interest, then I will blame her.

Student D (HP) also felt teachers should be blamed if they failed to teach well:

OK, $80 \%$ why I blame teachers (for my failure)? Not because I don't appreciate them, maybe the way of their teaching, maybe the syllabus, their approaches. I think all these factors contribute to $80 \%$ of the failure.

However, like student B, he also felt that effort should first come from himself.

We need to make an effort (to succeed) ... in order to succeed, you have to have, not passion, but you have to have this motivation to make yourself good... I think you're the one who makes whether you succeed or you fail. But in terms of how you succeed, if it is us who put in the effort, so $100 \%$ from us? ...Yes, I think from within. $100 \%$, if it's in that case because of individual effort.

Thus, it would appear that students who were ready to blame their teachers also felt that internal factors like effort and hard work were equally important in determining success and failure.

On the other hand, students $\mathrm{C}$ and $\mathrm{E}$, although classified as non-self-critical, clearly felt that the blame should be more on themselves if they failed to do well.

Student C (LP): Teacher only provides assistance (contributes) 20\%. 80\% comes from us. So, teacher is there just for support. We have to seek (learn) ourselves. But we are the ones who are weak in English. We have to look for all the stuff, teacher only helps $20 \%$.

Student E (LP) attributed success to teacher and blamed herself for failure:

Actually, the lecturer is the one who helps most. She is the one who supports us to master English.

I think the cause (of the failure) is myself. (I) did not do much practice. Lack of practice, lack of reading. That leads to lack of mastery. When we are about to 
master (it), when we have already mastered (it), we stop for a while. Then we forget again. After that, we start again.

The findings from the qualitative data are very intriguing. They reveal nuances of similarities and differences that could not possibly be detected by a quantitative analysis. Generally, it supports the quantitative data in showing that the students were generally teacher-centred and self-critical in nature with regard to their learning of English. Even learners who possessed autonomous characteristics and displayed inclination to blame their teachers when they failed to do well, were quick to admit that effort and hard work on their part were equally crucial to succeed in the learning of English. This pattern seems to run across proficiency levels too although the HP autonomous learners appeared more willing to blame their teachers.

\section{DISCUSSION}

The quantitative findings reveal that in general learners who displayed teacher-centred tendency were likely to be self-critical by attributing failure to internal factors. However, there is also some indication that HP autonomous learners were less self-critical and had greater tendency to blame external factors for failure. The qualitative findings, however, reveal that these HP learners acknowledged that personal factors were equally crucial for successful performance in the learning of English. These findings support Thang et al.'s (2011) postulation that Malaysian learners' self-critical tendency is, in part, explained by their tendency to respect their teachers, and together, both studies provide support in linking teacher-centredness and self-critical tendency in the learning of English that are prevalent among Malaysian university students.

These findings to a certain extent contradict those of Mori et al.'s (2011) quantitative study undertaken on students from six Malaysian universities. Their findings reveal Malaysian undergraduates who had high English proficiency level to be similar to Western students in that they attributed success more to their own effort and ability, and failure to class and interest-related factors. However, it has to be pointed out that this tendency is evident in the present study too although to a lesser extent and it was the qualitative component of this study that brought out the nuances of differences.

Additionally, the profound influence of English teachers on the learners and on their learning of English is apparent from the qualitative data. The learners regarded learning English from a teacher as a necessity. A teacher is not simply a knowledge provider or a source of reference but an advisor and a motivator as well. This is not surprising considering the way these learners were brought up. Malaysian learners as a result of an exam-oriented education system have been oriented into perceiving their teachers as the main provider of knowledge who have a major role in influencing their learning processes (Tengku Kasim \& Furbish, 2010). Moreover, the tendency to respect and think highly of their teachers has been instilled since young and is now ingrained within the learners (Abdul Majid et al. 1999; Philip \& Koo, 2006). The question that we would like to address here is whether this phenomenon is a problem.

As Thang et al. (2011) pointed out, Malaysian learners' tendency to attribute success to their teachers and to criticise themselves for failure had not led to negative effects in the 
sense that they are still capable of learning on their own. This is the case of learners in other Asian contexts too. In fact, the self-criticality prevalent among these learners is positive in certain aspects. As revealed in earlier studies (Gobel et al., 2011; Mori et al., 2011; Thang et al., 2011), these students tend to have a self-improving tendency. This can make them strive harder to address their weaknesses as they consider failures as features that they need to work on. This action, known as 'adjustment' (Morling, Kitayama, \& Miyamoto, 2002), allows them to fit better into the interdependent community in which they belong and which encourages conformity to other members' needs and expectations.

Nevertheless, the introduction of attribution training to these learners may be in order. This training involves transforming attribution styles that create a negative and undesirable achievement-related behaviour (Dörnyei, 2001). Enhancing learners' beliefs in their own personal contributions towards their academic performance can boost learners' self-confidence which motivates them to greater heights in their future careers. Teachers, have a role to play in this too. They can help in promoting positive causal attributions among their students so that they feel they are in control of their own success. In other words, learners must believe that without teachers they can still succeed. Therefore, they also need to believe that it is okay to be critical of their teachers and to voice this when necessary.

Another matter worth considering is whether it is necessary to label these learners as autonomous or teacher-centred. The answer is 'no'. What is more crucial for successful learning is the ability to exercise autonomy whenever they are required to do so and in whichever way that suits them best. This is described as 'reactive' autonomy by Littlewood (1999), and according to him, this type of autonomy "does not create its own directions but, once a direction has been initiated, it will enable learners to organise their resources autonomously in order to reach their goal" (p. 75). This capability has been established in studies conducted in Malaysia (Mohd Jaafar \& Thang, 2013; Thang, 2009; Thang \& Alias, 2007) and other Asian countries (Chia, 2009; Intratat, 2004).

Having said that, it does not mean that efforts should not be undertaken to promote a more student-centred and autonomous approach to teaching and learning. One major hurdle towards achieving this goal is the top-down education system in Malaysia. Teachers should be the agent of change and given the opportunity to engender them. Without this opportunity, teachers might suffer from lack of initiatives and creativity (Murugaiah, 2012). This situation is further aggravated by the highly exam-oriented system of education in Malaysia which focuses on grades in examination beyond anything else. This evidently suppresses learners' creativity and imagination (Kirkpatrick \& Zang, 2011), and produces students who depend blindly on their teachers to help them pass examinations (Mohd Nor, 2005). It is time to look seriously into this situation and undertake changes that address the root of these problems.

\section{CONCLUSION}

The findings suggest the profound role of socio-cultural factors in shaping the study participants' teacher-centred and self-critical tendencies and in shaping the relationship 
between the two. As such, the study provides another perspective worth pondering. Instead of viewing both tendencies as shortcomings, they should be seen as a unique trait of the community to which the learners belong. The tendencies, as elicited from the qualitative data, resulted from the learners' efforts as a member of the community to adapt and adjust to fit better in the community. These findings, albeit not generalisable due to the sampling technique, could nevertheless potentially explain similar tendencies evident in other Asian communities, especially those in countries that share similar topdown and exam-oriented education systems. Nonetheless, it has to be acknowledged that it is possible to change for the better. Thus, future directions for researchers on autonomy and attributions in Asian contexts should focus on coming up with ways to understand and exploit these unique tendencies and the students' high opinion and respect for their teachers to help to enhance students' learning processes. Studies that explore ways on how to strike an effective balance between these tendencies with the more 'western' autonomous and self-enhancing tendencies should be undertaken.

\section{REFERENCES}

Abdul Majid, S. Z., Hashim, M.Y., Ghazali, A. Z., Lee, K. H., Basri, A. F., \& Wahid, Z. A. (1999). Sejarah Malaysia Tingkatan 5. Kuala Lumpur. Malaysia: Dewan Bahasa dan Pustaka.

Benson, P. (2011). Teaching and researching autonomy in language learning. (2nd ed.). Harlow: Longman.

Chia, C. S. C. (2009). Is the Chinese culture of learning a barrier to fostering autonomous learning among PRC students? In S. M. Thang, \& B. Sinclair (Eds.), Learner autonomy: Research and practice in Malaysia and Singapore (pp. 34-60). Petaling Jaya, Malaysia: Pearson Malaysia.

Creswell, J.W. 2008. Educational research: Planning, conducting, and evaluating quantitative and qualitative research. 3rd Edition. New Jersey: Pearson Education.

Dörnyei, Z. (2001). Motivational strategies in the language classroom. Cambridge: Cambridge University Press.

Gobel, P., Mori S., Thang, S. M., Kan, N. H., \& Lee, K. W. (2011). The impact of culture on student attributions for performance: A comparative study of three groups of EFL/ESL learners. Journal of Institutional Research South East Asia (JIRSEA), 9, 27-43.

Holec, H. (1981). Autonomy in foreign language learning. Oxford: Pergamon.

Intratat, C. (2004). Investigation on IT autonomous learning: A case study from Thailand. Paper presented at UNTELE Conference, Universite de Compiegne, France.

Kirkpatrick, R., \& Zang, Y. (2011). The negative influences of exam-oriented education on Chinese high school students: Backwash from classroom to child. Language Testing In Asia, 1, 36-45.

Kitayama, S., Markus, H. D., Matsumoto, H., \& Norasakkunkit, V. (1997). Individual and collective process in the construction of the self: Self-enhancement in the United States and self-criticism in Japan. Journal of Personality and Social Psychology, 72, 1245-1267. 
Koo, Y. L., Thang, S. M., \& Lee, S. K. (2005). Investigating learner characteristics in the design of an online ESP programme: Learner readiness, identity and literacy in changing contexts. In S. H. Stapa, H. Azman, N. Abdul Razak, \& M. S. Abd Aziz (Eds.), Language policy and practice for nation building (pp. 101-125). Bangi, Malaysia: UKM.

Kruger, J. (1999). Lake Wobegon be gone! The "below-average effect" and the egocentric nature of comparative ability judgments. Journal of Personality and Social Psychology, 77, 221-232.

Littlewood, W. (1999). Defining and developing autonomy in East Asian contexts. Applied Linguistics, 20, 71-94.

Manusov, V., \& Spitzberg, B. H. (2008). Attributes of attribution theory: Finding good cause in the search for theory. In D.O. Braithwaite \& L.A. Baxter (Eds.), Engaging theories in interpersonal communication (pp. 37-49). Thousand Oaks, CA: Sage Publications.

Mohd Jaafar, N., \& Thang, S. M. (2013). Revisiting autonomy and attributions: A case in a Malaysian University. GEMA ${ }^{\circledR}$ Online Journal of Language Studies, 13, 41-64.

Mohd Nor, A. (2005). Teaching thinking skills: Redesigning classroom practices. Paper presented at Redesigning Pedagogy: Research, Policy, Practice Conference, Nanyang Technological University, Singapore.

Mori, S., Gobel, P., Thepsiri, K., \& Pojanapunya, P. (2010). Attributions for performance: A comparative study of Japanese and Thai university students. The Japan Association for Language Teaching (JALT) Journal, 32, 5-28.

Mori, S., Thang, S. M., Mohd Nor, N., Suppiah, V. L., \& Oon, S. I. (2011). Attribution tendency and its relationship with actual and perceived proficiency. GEMA ${ }^{\circledR}$ Online Journal of Language Studies, 11, 199-218.

Morling, B., Kitayama, S., \& Miyamoto, Y. (2002). Cultural practices emphasize influence in the United States and adjustment in Japan. Personality and Social Psychology Bulletin, 28, 311-323.

Murugaiah, P. (2012). Developing online communities of practice among Malaysian smart school teachers (Unpublished docrotal dissertatioan), Universiti Kebangsaan Malaysia, Malaysia.

Phan, T. T. T. (2012). Teacher autonomy and learner autonomy: An East Asian's perspective. International Journal of Social Science and Humanity, 2, 468-471.

Philip, B., \& Koo, Y. L. (2006). Social-motivational metacognitive strategy instruction (SMMS1z). Investigating autonomy of Malaysian ESL learners: A comparison between public and private universities. 3L: The Southeast Asian Journal of English Language Studies, 15, 97-124.

Tengku Kasim, T. S. A., \& Furbish, D. (2010). Transforming Malaysian teacher education for a sustainable future through student-centred learning. Proceeding the 
Annual Conference of the Australian Teacher Education Association (ATEA), Queensland, Australia.

Thang, S. M. (2012). A critical view of Malaysian ESL undergraduates' readiness for autonomy and its implication for Malaysian education curriculum. In Y. L. Koo, \& H. Azman (Eds.), Language and literacy in multilingual contexts: Issues and challenges (pp. 157-172). Bangi, Malaysia: UKM Press.

Thang, S. M., \& Alias, A. (2007). Investigating readiness for autonomy: A comparison of Malaysian undergraduates of three public universities. Reflections of ELT Journal, 6, $1-18$.

Thang, S. M., Gobel, P., Mohd Nor, N., \& Suppiah, V. L. (2011). Students' attributions for success and failure in the learning of English as a second language: A comparison of undergraduates. Pertanika Journal of Social Sciences \& Humanities, 19, 459-474.

Vispoel, W., \& Austin, J. (1995). Success and failure in Junior High School: A critical incident approach to understanding students' attributional beliefs. American Educational Research Journal, 32, 377-412.

Weiner, B. (1974). An attributional interpretation of expectancy-value theory. In B. Weiner (Ed.), Cognitive views on human motivation (pp. 51-69). New York: Academic Press, Inc.

Weiner, B. (1992). Human motivation: Metaphors, theories, and research. Newbury Park, CA: Sage Publications, Inc.

\section{Turkish Abstract \\ Öğretmen Merkezli ve Kendini Eleştirmeye Eğilimli İkinci Dil Olarak İngilizce Öğrenen (ESL) Malezyalılar Arasındaki Etkileşim}

Geçen 10 yılda, Asyalı araştırmacılar arasında İngilizce öğrenenlerdeki başarı ve başarısızlıklara ilişkin yapılan nitelikli yayınlar gözden geçirilmiştir. Asyalı öğrencilerin İngilizce öğrenmedeki başarısızlıkları için kendini eleştirmeye eğilimli olmaları bu konuda araştırma alanı olmuştur. Bu eğilim genel olarak çoğu Asya ülkesinde ki gibi birlikte yaşayan toplumlarda yetişmiş karakterler arasındaki sosyo kültürel içerikle ilgilidir. Buna ilave olarak bu davranışa katkı sağlayan faktör bu öğrencilerin öğretmenlerine karşı çok saygılı davranmalarıdır. Araştırma, bu davranıșın doğruluk boyutlarını araştırmaya yönelik yapılmıştır. Araştırmacılar Malezya koşullarındki farklı uzmanlık seviyelerindeki İngilizce öğrenenler arasında kendini eleştirmeye eğilimli ve öğretmen merkezli davranışlar arasında ilişki olup olmadığını incelemiştir.

Anahtar Kelimeler: bağımsızlık, öğretmen mekezli öğrenme, kendini eleștirmeye eğilim, ikinci dil olarak İngilizce 


\section{French Abstract}

L'Interaction entre Fait d'être centré de professeur et Tendance Autocritique parmi anglais seconde langue malais (ESL) Apprenants

$\mathrm{Au}$ cours de la décennie dernière, les questions(publications) quant aux attributions pour le succès et l'échec dans l'apprentissage d'anglais ont engrangé(recueilli) beaucoup d'intérêt parmi des chercheurs asiatiques. D'intérêt particulier est la tendance d'apprenants asiatiques pour être autocritique lorsqu'il s'agit des attributions pour l'échec dans l'apprentissage d'anglais. Cette tendance était généralement liée avec l'influence du contexte socioculturel dans lequel les apprenants ont grandi et a été décrit comme un trait répandu parmi des sociétés collectivistes comme ceux qui existent dans beaucoup de pays asiatiques. Plus récemment, il a été suggéré qu'un facteur contribuant pour ce comportement est le haut respect des étudiants de professeurs. L'étude présente était une tentative d'examiner dans quelle mesure cette réclamation est vraie. Les chercheurs ont examiné si vraiment il y a une relation entre la tendance autocritique et le fait d'être centré de professeur entre les étudiants de niveaux de compétence différents dans l'apprentissage d'anglais dans un contexte malais.

Mots Clés: autonomie; attribution; apprentissage centré sur professeur; tendance autocritique, anglais seconde langue

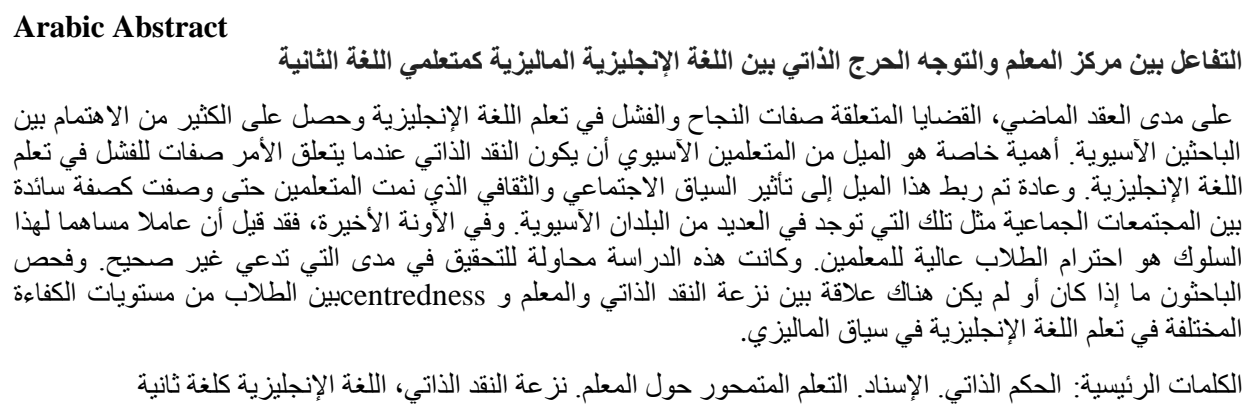

\section{German Abstract}

Das Zusammenspiel von Lehrer-Centredness und Selbst-kritische Tendenz unter malaysischen Englisch als Zweitsprache (ESL) Lernenden

Im Laufe des letzten Jahrzehnts haben Fragen der Zuordnung von Erfolg und Misserfolg beim Englischlernen viel Interesse an asiatischen Forschern gesammelt. Von besonderem Interesse ist die Tendenz der asiatischen Lernenden, selbstkritisch zu sein, wenn es um Attributionen für das Versagen im Lernen von Englisch geht. Diese Tendenz hat sich häufig mit dem Einfluss des soziokulturellen Kontextes verknüpft, in dem die Lernenden aufgewachsen sind und als eine weit verbreitete Eigenschaft unter kollektivistischen Gesellschaften beschrieben wurden, wie sie in vielen asiatischen Ländern existieren. Vor kurzem wurde vorgeschlagen, dass ein Faktor für dieses Verhalten der Studenten hohen Respekt vor den Lehrern ist. Die vorliegende Studie war ein Versuch zu untersuchen, inwieweit diese Behauptung wahr ist. Die Forscher untersuchten, ob es eine Beziehung zwischen selbstkritischen Tendenz und Lehrer-Centredness zwischen Studenten der verschiedenen Kompetenz Ebenen in das Lernen von Englisch in einem malaysischen Kontext.

Schlüsselwörter: autonomie, attribution, lehrerzentriertes lernen, selbstkritische tendenz, Englisch als zweitsprache 


\author{
Malaysian Abstract \\ Interaksi antara Pergantungan terhadap Guru dan Kecenderungan Mengkritik Diri Sendiri \\ dalam kalangan Pelajar Malaysia yang Mempelajari Bahasa Inggeris sebagai Bahasa Kedua \\ (ESL)
}

Isu-isu mengenai punca kejayaan dan kegagalan dalam pembelajaran Bahasa Inggeris telah menarik minat ramai penyelidik Asia. Yang menarik adalah kecenderungan pelajar Asia untuk mengkritik diri sendiri apabila gagal dalam pembelajaran bahasa Inggeris. Kecenderungan ini biasa dikaitkan dengan pengaruh konteks sosio-budaya di mana pelajar telah dibesarkan. Ia juga digambarkan sebagai sifat lazim dalam kalangan masyarakat kolektivis seperti yang wujud di negara-negara Asia. Baru-baru ini, ada dicadangkan bahawa satu faktor penyumbang kepada kecenderungan ini adalah sikap pelajar memberi penghomatan yang tinggi terhadap guru. Kajian ini adalah satu usaha untuk mengkaji sejauh mana kebenaran cadangan tersebut. Para penyelidik mengkaji sama ada wujudnya hubungan antara kecenderungan untuk bersikap kritikal terhadap diri sendiri dengan kecenderungan para pelajar untuk bergantung kepada guru. Kajian ini dibuat dalam konteks pembelajaran bahasa Inggeris sebagai bahasa kedua di Malaysia.

Kata Kunci: autonomi, atribusi, pembelajaran bersandarkan guru, kecenderungan mengkritik diri sendiri, Bahasa Inggeris sebagai bahasa kedua

\title{
Russian Abstract \\ Взаимодействие Между Учителями Центральной (Азии) и Самокритика Среди Учащихся, Малазийского Английского, Как Второго Языка (ESL)
}

За За последнее десятилетие, проблемы родственной атрибуции успехов и неудачи в изучении Английского Языка вызвали большой интерес среди Азиатских исследователей. Особый интерес представляют Азиатские учащиеся, характеризующиеся достаточной самокритичностью, когда дело доходит до приписывания неудач при изучении английского языка. Эта тенденция была связана влиянием социокультурного контекста, в котором выросли учащиеся, и была описана как преобладающая черта среди коллективистских обществ, таких как те, которые существуют во многих Азиатских Странах. В последнее время было высказано предположение, что фактором, способствующим этому поведению, является высокое уважение учеников к учителям. Данное исследование включает цель - расследовать в какой степени, данное утверждение верно. Исследователи изучили, существует ли связь между самокритикой учащихся и влияние учителя на учащихся, профессионализм учителя в изучении английского языка в Малазийском контексте.

Ключевые Слова: автономия Атрибуция, Обучение, центральной на учителя, Самокритичная тенденция, английский как второй язык 